Abstracta Iranica

Revue bibliographique pour le domaine irano-aryen

Volume 32-33 | 2013

Comptes rendus des publications de 2009-2010

\title{
Eric Wright. Eastern Christianity: A Look at Its Foundation and History
}

\section{Florence Jullien}

\section{(2) OpenEdition \\ 12 Journals}

Édition électronique

URL : http://journals.openedition.org/abstractairanica/40908

DOI : 10.4000/abstractairanica.40908

ISSN : 1961-960X

\section{Éditeur :}

CNRS (UMR 7528 Mondes iraniens et indiens), Éditions de l'IFRI

\section{Édition imprimée}

Date de publication : 1 décembre 2013

ISSN : 0240-8910

\section{Référence électronique}

Florence Jullien, « Eric Wright. Eastern Christianity: A Look at Its Foundation and History », Abstracta Iranica [En ligne], Volume 32-33 | 2013, document 355, mis en ligne le 01 juillet 2016, consulté le 26 septembre 2020. URL : http://journals.openedition.org/abstractairanica/40908 ; DOI : https://doi.org/ 10.4000/abstractairanica.40908

Ce document a été généré automatiquement le 26 septembre 2020.

Tous droits réservés 


\title{
Eric Wright. Eastern Christianity: A Look at Its Foundation and History
}

\author{
Florence Jullien
}

\section{RÉFÉRENCE}

Eric Wright. Eastern Christianity: A Look at Its Foundation and History. Webster's Digital Services, 2010, $226 \mathrm{p}$.

1 Ces deux ouvrages parus conjointement ne sont pas œuvres de spécialistes mais le fruit d'une synthèse de données encyclopédiques prises sur internet, sans regard critique et sans accès direct aux sources. Cette méthode est celle que proposent les éditeurs de la collection promue par Webster's Digital Services, qui ne prétend à aucun travail de type scientifique mais plutôt compilatoire.

2 [Ce compte rendu concerne également le $\mathbf{n}^{\circ}$ 354]

\section{AUTEURS}

FLORENCE JULLIEN

EPHE, Paris 